\title{
Chemical inhibition of bacterial colonization by the red alga Bonnemaisonia hamifera
}

\author{
G. M. Nylund ${ }^{1, *}$, G. Cervin ${ }^{1}$, M. Hermansson ${ }^{2}$, H. Pavia ${ }^{1}$ \\ ${ }^{1}$ Department of Marine Ecology, Tjärnö Marine Biological Laboratory, Göteborg University, 45296 Strömstad, Sweden \\ ${ }^{2}$ Department of Cell and Molecular Biology, Microbiology, Göteborg University, Box 462, 40530 Göteborg, Sweden
}

\begin{abstract}
Attachment and growth are 2 major processes in bacterial colonization of surfaces in the sea. By inhibiting either or both of these processes, marine macroorganisms may defend themselves against bacterial infection and fouling. We tested crude extracts from 5 red seaweed species for their ability to inhibit bacterial growth and attachment. For this we used 11 strains of bacteria, representing 5 different taxonomic groups. The effects on growth and attachment were tested by a standard disc-diffusion assay and by incorporating crude extracts into phytagel blocks that served as a surface for bacterial attachment. Extracts from one of the tested algae, Bonnemaisonia hamifera, were particularly active and inhibited growth of 9 bacteria at concentrations volumetrically equivalent to whole algal tissue, or lower. The other 4 algal extracts had weak growth-inhibiting effects on only a few bacterial strains. None of the algal extracts exhibited broad-spectrum effects against bacterial attachment, but 4 of 5 algal extracts had some strain-specific effects. Surface extracts of $B$. hamifera tested on bacteria showed that metabolites are naturally present at sufficiently high concentrations in order to inhibit bacterial growth on the surface of the seaweed. In situ quantification of bacteria on $B$. hamifera also showed that this alga had significantly fewer bacteria on its surface compared to a coexisting alga. These findings suggest that $B$. hamifera naturally reduces its epibacterial abundance by production of broad-spectrum growth-inhibiting secondary metabolites. This is one of a few examples where ecologically relevant effects of algal metabolites on bacterial colonization have been shown.
\end{abstract}

KEY WORDS: Epibiosis - Bacterial attachment - Antimicrobial activity · Chemical defence · Antifouling $\cdot$ Red algae $\cdot$ Bonnemaisonia hamifera

\section{INTRODUCTION}

In the marine environment, surfaces are rapidly covered with an organic layer due to adsorption of inorganic and organic molecules and subsequent colonization by bacteria, protozoa, algae and fungi (Wahl 1989, Clare 1996). Provided the surfaces are living organisms, this phenomenon is referred to as epibiosis (Wahl 1989). Bacterial epibiosis on benthic macroalgae (seaweeds) can be both beneficial and deleterious to host algae. For instance, bacteria isolated from algal surfaces may produce compounds that deter settlement of other surface-colonizing organisms (Egan et al. 2000, Dobretsov \& Qian 2002). However, bacterial epibiosis can also have negative impacts on seaweeds by providing positive settlement cues for macroscopic fouling organisms $\left(\mathrm{O}^{\prime}\right.$ Connor \& Richardson 1996, Wieczorek \& Todd 1997, Unabia \& Hadfield 1999). Furthermore, bacteria may cause tissue damage in algae (Littler \& Littler 1995, Vairappan et al. 2001), which in some situations can have devastating effects on whole ecosystems (Littler \& Littler 1995).

Seaweeds may defend themselves against bacterial fouling by physical means, such as sloughing of the outermost cell layers (Johnson \& Mann 1986, Keats et al. 1997, Nylund \& Pavia 2005), by physiological responses, such as oxidative bursts (Collen et al. 1995, Weinberger \& Friedlander 2000), or by production of secondary metabolites, that prevent attachment and growth of bacteria (Maximilien et al. 1998). Seaweeds 
are rich in secondary metabolites (see Tringali 1997), and earlier (summarized by Aubert et al. 1979, Sridhar \& Vidyavathi 1991) as well as more recent studies (e.g. Hellio et al. 2000, 2001), have shown that many macroalgae produce metabolites with antibacterial activities. Most of these studies have focused on growthinhibiting activities, but as recent research has shown, algal secondary metabolites may also influence bacterial epibiosis by mechanisms other than growth inhibition. For example, the low abundances of bacteria on the red algae Delisea pulchra could not be ascribed to any effects of crude extracts, or pure compounds, on bacterial growth. Instead, bacterial abundances seemed to be controlled by production of secondary metabolites that specifically affected bacterial attachment (Maximilien et al. 1998). Studies on metabolites from organisms other than algae also show a lack of correlation between growth-inhibiting activity and bacterial attachment (i.e. Wahl et al. 1994, Slattery et al. 1995, Harder et al. 2003, Kelly et al. 2003). As these examples show, tests of effects on bacterial growth are insufficient when searching for compounds with defensive roles against microbial colonization. Attachment, which reflects multiple aspects of the colonization process such as chemotactic responses and adhesion mechanisms, is also a major process that potentially regulates bacterial epibiosis on algae. Therefore, a combination of bacterial growth and attachment tests would be a logical approach when searching for metabolites that naturally regulate epibacterial abundances on algae or other marine organisms.

In this study, we screened the antibacterial effects of crude extracts from 5 different red algal species that are common on the west coast of Sweden. The extracts were tested for their effects on both bacterial growth and attachment against 11 strains of bacteria representing 5 different taxonomic groups, in order to detect possible broad-spectrum effects. Based on the results from the screening experiments, we further tested if one of the algae, Bonnemaisonia hamifera, has growth-inhibiting metabolites present on its surface. This was done by extracting metabolites from the algal surface without co-extracting the interior of the algal cells, according to the dip method described by de Nys et al. (1998). Bacterial growth inhibition tests with the surface extracts showed that this alga has metabolites present on its surface in sufficiently high amounts to inhibit bacterial growth. Based on these results, we further hypothesized that natural populations of $B$. hamifera would have lower epibacterial abundances compared to a co-existing alga that caused no significant inhibition of bacterial growth in the growth inhibition tests. This hypothesis was tested by comparing the natural abundances of bacteria on the algal surfaces.

\section{MATERIALS AND METHODS}

Preparation of extracts. The 5 algal species selected for chemical extraction were the tetrasporangial phase (i.e. the Trailiella-phase) of Bonnemaisonia hamifera Hariot, 1891, Chondrus crispus Stackhouse, 1797, Dilsea carnosa (Schmidel) Kuntze 1898, Osmundea ramosissima (Oeder) Athanisiadis 1996 and Polyides rotundus (Hudson) Greville 1830. The algae were collected by scuba diving in the archipelago west of Tjärnö Marine Biological Laboratory, on the west coast of Sweden. Within a few hours, the algae were drained of excess water and freeze dried. The freeze-dried algae were weighed, homogenized and extracted 3 times with dichloromethane. The resulting solution was filtered and the dichloromethane was removed by rotary evaporation. This procedure was repeated with 1:1 dichloromethane:methanol and then methanol, and all of the obtained extracts were combined to a single fraction. This procedure was repeated for all the algal species and the resulting extracts were transferred to pre-weighed scintillation vials, dried under a stream of nitrogen, weighed, and stored in a freezer at $-70^{\circ} \mathrm{C}$ until used in bioassays.

In order to relate the test concentrations of extracts for the bioassays to the total amount of extractable compounds in the seaweeds, we quantified the specific volume:dry weight and surface area:dry weight ratios for each algal species by the following procedure. Volume measurements were conducted by displacement in a graduated cylinder filled with seawater. Area measurements of foliose algae were conducted by determining the surface area of photographed pieces of algae with the picture analyzing software Carnoy 2.1 (Peter Schols, Laboratory of Plant Systematics, Katholieke Universiteit Leuven). The surface areas of filamentous algae were determined by measuring the volume and the average diameter of the filaments. The algae were visualized as cylinders where each filament contributed to the length of the cylinder and the surface areas were calculated by using the common formulas for volume and area computations of cylinders. The algal pieces from the volume and area measurements were dried in a freeze drier and subsequently weighed, whereupon the specific volume:dry weight and surface area:dry weight ratios could be calculated. From these ratios, we calculated the test concentrations by relating the amount of extracts yielded from algal tissue samples that were volumetrically equivalent to the paper disc (for the agar discdiffusion assay), or from algal tissue samples with the same surface area as the test system (for the attachment test). These values were considered to be the highest possible test concentrations with ecological relevance. However, these values were probably over- 
estimations, since the total amount of an active metabolite contained in an alga cannot be presented only at the surface, or be released to the surrounding water. Still, we assumed that these concentrations would be reasonable to start with since a lack of inhibition of bacterial growth and/or attachment with algal extracts tested at these concentrations would imply that the algae do not produce metabolites with ecologically relevant broad-spectrum effects against bacterial colonization.

Bacterial strains and culture media. Most of the bacterial strains used in the experiments have been found in seawater (Table 1). Identities, sources and growth conditions of the bacteria are given in Table 1. All the stock cultures were stored in glycerol in a freezer at $-70^{\circ} \mathrm{C}$, while growing bacteria were maintained on nutritive agar plates. The culture media used were Luria-Bertani medium (LB) (Maniatis et al. 1982), LB supplemented with $\mathrm{NaCl}$ to a final concentration of $1.5 \%$ (LB15), nutrient agar (NA) (Oxoid CM3), and bacto marine medium 2216 (BMM) (Difco). The bacterial cultures were grown for 24 to $48 \mathrm{~h}$ in appropriate nutrient broth before being used in the assays.

Inhibition of bacterial growth. Growth-inhibiting activities of the different algal extracts were investigated by a standard agar disc-diffusion assay on appropriate nutritive agar with replication $(\mathrm{n}=5)$. The extracts were tested at $10 \mu \mathrm{g} \mathrm{\mu l}^{-1}$ for each algal species, in order to allow for comparisons of the activity of extracts among the algal species. The algal extracts were re-dissolved in methanol and pipetted onto circular paper discs (Oxoid; disc volume $15 \mu \mathrm{l}$ ), which were air-dried and placed on agar plates, with 1 disc per agar plate. Control discs with only methanol added were also prepared. Assays were run at appropriate temperatures until control bacteria developed a confluent film (18 to $48 \mathrm{~h}$ ). The observed diameters of the growth inhibition zones were measured to the nearest $1 \mathrm{~mm}$ with a ruler, and a mean value was calculated from the different replicates. Based on the results from these tests, we also tested the effect on bacterial growth of the extract of one of the algal species, Bonnemaisonia hamifera, at a lower concentration $\left(1 \mu \mathrm{g} \mathrm{l}^{-1}\right)$. These tests were conducted in a similar manner as the previous growth inhibition tests.

Inhibition of bacterial attachment. Inhibition of bacterial attachment was assayed according to Harder et al. (2003). Aliquots of seaweed extracts dissolved in methanol were evaporated on micro slides, which resulted in circular areas of dry extract residues, approximately $10 \mathrm{~mm}$ in diameter. The concentrations of the extract residues were $500 \mu \mathrm{g} \mathrm{cm}^{-2}$ for all algal extracts except for the extract of Bonnemaisonia hamifera, where the concentration was $50 \mu \mathrm{g} \mathrm{cm}^{-2}$. Methanol was applied accordingly and served as a negative control. The micro slides were covered by phytagel $(2.7 \%$ wet mass) to form an even layer of $1 \mathrm{~mm}$ thickness. We used phytagel instead of agar because pilot studies showed that several bacterial strains attached in greater number on phytagel (data not shown). Following a $2 \mathrm{~h}$ incubation period to allow for diffusion of the extract components through the phytagel matrix, the micro slides were transferred to staining jars filled with a bacterial suspension diluted to slightly more than $10^{8}$ cells $\mathrm{ml}^{-1}$ with either sterile $\mathrm{MQ}$ water or filtered seawater, depending on the

Table 1. Identities, sources and growth conditions of the bacteria included in this study. NA: nutrient agar; BMM: bacto marine medium 2216; LB: Luria-Bertani medium; LB15: LB supplemented with $\mathrm{NaCl}$ to a final concentration of $1.5 \%$; Rif: rifampicin; Nx: nalidixic acid; CCUG: Culture Collection of Göteborg University; NCIMB: National Collection of Industrial and Marine Bacteria

\begin{tabular}{|c|c|c|c|}
\hline Taxonomic group and strain & Marine relevance & Growth conditions & Source/Reference \\
\hline \multicolumn{4}{|l|}{ Proteobacteria (gamma group) } \\
\hline Aeromonas hydrophila & Marine occurrence & $\mathrm{NA} / 30^{\circ} \mathrm{C}$ & CCUG 14551 \\
\hline Pseudoalteromonas atlantica & Marine isolate & $\mathrm{BMM} / 20^{\circ} \mathrm{C}$ & NCIMB 301 \\
\hline Escherichia coli LE392 & & $\mathrm{LB} / \operatorname{Rif}^{\mathrm{r}} / 30^{\circ} \mathrm{C}$ & Bale et al. (1988) \\
\hline Pseudomonas fluorescens & Marine occurrence & $\mathrm{NA} / 20^{\circ} \mathrm{C}$ & CCUG 1253 \\
\hline Pseudomonas putida KT2440 & Marine occurrence & $\mathrm{LB} 15 / \mathrm{Nx}^{\mathrm{r}} / 25^{\circ} \mathrm{C}$ & S. Molin \\
\hline Vibrio sp. S14 & Marine isolate & $\mathrm{BMM} / 25^{\circ} \mathrm{C}$ & S. Kjelleberg \\
\hline \multicolumn{4}{|l|}{ Proteobacteria (alpha group) } \\
\hline Hyphomonas neptunicum & Marine isolate & $\mathrm{BMM} / 25^{\circ} \mathrm{C}$ & NCIMB 2223 \\
\hline \multicolumn{4}{|l|}{ Gram-positive bacteria (high GC) } \\
\hline Micrococcus luteus & Marine occurrence & $\mathrm{NA} / 30^{\circ} \mathrm{C}$ & CCUG 5838 \\
\hline \multicolumn{4}{|l|}{ Gram-positive bacteria (low GC) } \\
\hline Listeria murrayi & & $\mathrm{NA} / 30^{\circ} \mathrm{C}$ & CCUG 4984 \\
\hline Planococcus sp. & Marine isolate & $\mathrm{BMM} / 20^{\circ} \mathrm{C}$ & NCIMB 1097 \\
\hline \multicolumn{4}{|l|}{ Bacteroides, Flavobacteria } \\
\hline Flavobacterium brevi & & $\mathrm{NA} / 25^{\circ} \mathrm{C}$ & CCUG 7320 \\
\hline
\end{tabular}


growth media of the bacteria. Preliminary studies with an algal crude extract that was known to inhibit the attachment of the bacteria Pseudomonas fluorescens had shown that a $2 \mathrm{~h}$ incubation was long enough to allow for the active components of the extract to diffuse to the surface of the phytagel in sufficient amounts to inhibit attachment of the bacteria (data not shown). After 30 min of incubation with shaking, the micro slides were thoroughly dip-rinsed in appropriate water to remove unattached bacteria. The bacterial abundance of attached bacteria on the treated micro slides was then determined by phase-contrast microscopy (Leitz Diaplan microscope) at a magnification of 1000x in 10 randomly chosen unit fields $\left(0.01 \mathrm{~mm}^{2}\right)$ and compared to controls. The extract and control treatments were replicated 3 times $(n=3)$.

Extraction of surface-associated metabolites from Bonnemaisonia hamifera. Based on the results from the bacterial growth inhibition tests and the attachment tests, we further investigated whether bacterial growth-inhibiting metabolites are present on the surface of Bonnemaisonia hamifera. This was done according to the dip method described by de Nys et al. (1998), which allows non-polar metabolites at the surface of the algal thallus to be extracted without coextracting the interior of the algal cells. Algal thalli of $B$. hamifera were collected by scuba diving in the archipelago west of Tjärnö Marine Biological Laboratory, and stored in an aquarium with a continuous flux of seawater until used for extractions. A mixture of hexane and MQ water (1:1) was used as an extraction solvent, because a non-polar solvent like hexane made the algal thallus inaccessible for extraction by heavily clumping together the small filaments of $B$. hamifera (the algal thallus consists of numerous small single celled filaments, approximately 20 to $30 \mu \mathrm{m}$ wide). On the other hand, more polar solvents, in this case dichloromethane and mixtures of dichloromethane and hexane, avoided the clumping of the filaments but caused the epithelial cells to rapidly lyse. Using the 1:1 mixture of hexane and $\mathrm{MQ}$ water, we extracted individual pieces of $B$. hamifera $(\mathrm{n}=6)$ for $0,5,10,20,30$ and $40 \mathrm{~s}$ and measured the effect on cell lysis by epifluorescence microscopy at a magnification of 250x (Olympus BX 51 microscope, fluorescens mirror unit U-MWB2). The extractions were done in glass vials on a vortex. The effect of extraction time was directly assessed following extraction by counting the number of lysed versus intact cells in 5 different fields of view $\left(0.17 \mathrm{~mm}^{2}\right)$ for tissue from each extraction time. Based on the result of these extractions, 10 pieces (ca. $30 \mathrm{mg}$ wet weight) of tissue of different individuals of $B$. hamifera were separately extracted for $20 \mathrm{~s}$ in $6 \mathrm{ml}$ of the 1:1 hexane-MQ water mixture. The algal tissues were removed by filtration and the filtrates of all of the 10 extractions were pooled together in a glass test tube. The test tube was rigorously shaken and left standing until a clear water and hexane layer had been formed. The hexane phase was then transferred with a Pasteur pipette to glass vials, which were stored in a freezer at $-70^{\circ} \mathrm{C}$ until used in bioassays.

Inhibition of bacterial growth by surface extracts of Bonnemaisonia hamifera. Based on a surface area:wet weight ratio for Bonnemaisonia hamifera, the surface extracts were diluted and pipetted onto circular paper discs (Oxoid; disc volume $15 \mu \mathrm{l}$ ), so that the final concentrations on the paper discs corresponded to 1,2 and 5 times the amount of surface extracts yielded from algal tissue samples with the same surface area as the paper discs (hereafter termed the natural concentration of surface metabolites). The surface extracts were tested at higher concentrations than the natural concentration, since we did not now how efficient the surface extraction procedure was in extracting all surfaceassociated non-polar metabolites. Furthermore, only $71 \%$ of the hexane used in the extractions was recovered. The paper discs were air-dried and placed on agar plates, 1 disc per agar plate $(n=3)$. Control discs with only hexane added were also prepared. The surface extracts were tested against the growth of 3 marine bacteria (Hyphomonas neptunicum, Planococcus sp. and Vibrio sp. S14). Assays were run in a similar manner to the previous growth inhibition tests.

In situ quantification of bacteria on the surface of Bonnemaisonia hamifera. Co-existing algal individuals of Bonnemaisonia hamifera and Chondrus crispus were collected by scuba diving from a locality west of Tjärnö Marine Biological Laboratory, and immediately after arriving to the laboratory, the bacterial abundances on the algal surfaces were quantified with epifluorescence microscopy using a narrow band mirror unit that cut off wavelengths above $460 \mathrm{~nm}$ (Olympus BX 51 microscope, fluorescens mirror unit U-MNUA2). Individuals of the algal species $(\mathrm{n}=10)$ were stained with 4'6-diamidino-2-phenylindole (DAPI, $0.4 \mu \mathrm{g} \mathrm{ml}^{-1}$ ) for $5 \mathrm{~min}$, and the bacterial abundances were then quantified by direct counts of blue fluorescent cells at a magnification of 1000x in 10 randomly-chosen unit fields $\left(0.002 \mathrm{~mm}^{2}\right)$. C. crispus was chosen as a control alga, because it co-exists with $B$. hamifera at the locality where the algae were collected, and because the growth inhibition tests had shown that whole cell extracts of this alga had no significant effects on bacterial growth.

Statistical analyses. The homogeneity of variances for the obtained data from the attachment assays, the test on the effect of extraction time on lysis of surface cells of Bonnemaisonia hamifera, and the investigation of bacterial abundances on algal surfaces were tested with Cochran's test and transformed when 
required to fulfill the requirement of homogenous variances, prior to further statistical analyses (Underwood 1997). The results from the growth inhibition tests were analyzed by calculating the $95 \%$ confidence intervals for the observed inhibition zones and by comparing them to zero (i.e. the inhibition zone of the controls). The data from the attachment assays and the test on the effect of extraction time on cell lysis were log-transformed (when required) and arcsin transformed, respectively. The results from the attachment assays and the investigation of bacterial abundances on algal surfaces were analyzed by analysis of variance (ANOVA). The result from the test on the effect of extraction time on cell lysis was also analyzed by ANOVA followed by a StudentNewman-Keuls test (SNK-test) (Underwood 1997).

\section{RESULTS}

\section{Extraction yields and test concentrations}

The amount of extracts yielded from whole cell extractions of freeze-dried samples of the different seaweed species is presented in Table 2. The test concentrations of the different extracts used in the growth inhibition and the attachment tests are also given in Table 2.

\section{Inhibition of bacterial growth}

The results from the disc-diffusion assays are shown in Table 3. Crude extracts of the different algae had different effects on bacterial growth. The extract of Bonnemaisonia hamifera was the most effective and inhibited growth of 9 of 11 tested bacterial species at $10 \mu \mathrm{g} \mathrm{ll}^{-1}$. At a lower concentration, $1 \mu \mathrm{g} \mathrm{ll}^{-1}$, the B. hamifera extract inhibited 2 bacterial strains, Aeromonas hydrophila and Flavobacterium brevi (the inhibition zones were with $95 \%$ confidence limits $1.0 \pm$
0.6 and $4.2 \pm 0.7 \mathrm{~mm}$, respectively). The extracts of the other algal species had much less growth-inhibiting effects. The extracts of Chondrus crispus and Dilsea carnosa tested at $10 \mu \mathrm{g} \mathrm{ll}^{-1}$ inhibited the growth of 2 bacterial strains, while the extract of Osmundea ramosissima inhibited 1 bacterial strain. The inhibition zones were, however, generally smaller compared to the tests with $B$. hamifera extract. The extract of Polyides rotundus had no effect on bacterial growth. The methanol controls had no effect on growth at any instance (data not shown).

\section{Inhibition of bacterial attachment}

The results of the bacterial attachment tests are shown in Fig. 1. Four of the bacteria, Escherichia coli LE392, Micrococcus luteus, Planococcus sp. and Vibrio sp. S14, were excluded from the attachment tests, since these bacteria did not attach in sufficient numbers to the phytagel surface. The effects of the different extracts varied between bacterial species. Extracts of Chondrus crispus, Dilsea carnosa and Osmundea ramosissima were the most effective, where each of the extracts significantly inhibited attachment of 2 of 7 bacterial strains at the tested concentration. Furthermore, there was a tendency of inhibition of 1 additional bacterial strain by the $C$. crispus extract. The extracts of Bonnemaisonia hamifera significantly inhibited 1 bacterium, while the extracts of Polyides rotundus did not inhibit bacterial attachment in any assay. A significant stimulation of bacterial attachment was only observed in 1 assay.

\section{Effects of extraction time on cell viability}

Dipping pieces of Bonnemaisonia hamifera tissue in a 1:1 hexane-water mixture for different time periods resulted in a significant effect of immersion time on lysis of surface cells (ANOVA, $F_{5,30}=32.72$, $p<0.0001$ ).

Table 2. Amount of extracts yielded from whole cell extractions of freeze-dried samples of Bonnemaisonia hamifera, Chondrus crispus, Dilsea carnosa, Osmundea ramosissima and Polyides rotundus. Test concentrations of the different algal extracts used in the growth inhibition and the attachment tests are also given

\begin{tabular}{|c|c|c|c|c|}
\hline \multirow[t]{2}{*}{ Seaweed species } & \multicolumn{2}{|c|}{ Extraction yield ${ }^{\mathrm{a}}$} & \multirow{2}{*}{$\begin{array}{l}\text { Test concentrations, } \\
\text { growth assays }\left(\mu \mathrm{g} \mathrm{ll}^{-1}\right)\end{array}$} & \multirow{2}{*}{$\begin{array}{l}\text { Test concentrations, } \\
\text { attachment assays }\left(\mu \mathrm{g} \mathrm{cm}{ }^{-2}\right)\end{array}$} \\
\hline & & $\mu \mathrm{g} \mathrm{cm}^{-2}$ & & \\
\hline Bonnemaisonia hamifera & 34 & 25 & 10 & 50 \\
\hline Chondrus crispus & 11 & 473 & 10 & 500 \\
\hline Dilsea carnosa & 18 & 594 & 10 & 500 \\
\hline Osmundea ramosissima & 29 & 858 & 10 & 500 \\
\hline Polyides rotundus & 8 & 283 & 10 & 500 \\
\hline
\end{tabular}


Table 3. Growth-inhibiting activities of extracts (compound concentration: $10 \mu \mathrm{g} \mathrm{l}^{-1}$ ) from Bonnemaisonia hamifera, Chondrus crispus, Dilsea carnosa, Osmundea ramosissima and Polyides rotundus against different bacterial strains. Data are inhibition zones in $\mathrm{mm} \pm 95 \%$ confidence interval (the diameter of the inhibition zone minus the diameter of the test disc); - : no inhibition

\begin{tabular}{|c|c|c|c|c|c|}
\hline Test bacteria & $\begin{array}{c}\text { Bonnemaisonia } \\
\text { hamifera }\end{array}$ & $\begin{array}{l}\text { Chondrus } \\
\text { crispus }\end{array}$ & $\begin{array}{c}\text { Algal extract } \\
\text { Dilsea } \\
\text { carnosa }\end{array}$ & $\begin{array}{l}\text { Osmundea } \\
\text { ramosissima }\end{array}$ & $\begin{array}{l}\text { Polyides } \\
\text { rotundus }\end{array}$ \\
\hline \multicolumn{6}{|l|}{ Proteobacteria (gamma group) } \\
\hline Aeromonas hydrophila & $5.8 \pm 0.4$ & $1.2 \pm 0.4$ & - & - & - \\
\hline Pseudoalteromonas atlantica & $2.0 \pm 0.0$ & - & $1.2 \pm 0.4$ & - & - \\
\hline Escherichia coli LE392 & - & - & - & - & - \\
\hline Pseudomonas fluorescens & $2.0 \pm 1.2$ & - & - & $1.8 \pm 1.0$ & - \\
\hline Pseudomonas putida KT2440 & - & - & - & - & - \\
\hline Vibrio sp. S14 & $5.4 \pm 0.5$ & - & - & - & - \\
\hline \multicolumn{6}{|l|}{ Proteobacteria (alpha group) } \\
\hline Hyphomonas neptunicum & $13.0 \pm 0.6$ & - & - & - & - \\
\hline \multicolumn{6}{|l|}{ Gram-positive bacteria (high GC) } \\
\hline Micrococcus luteus & $13.0 \pm 0.6$ & - & - & - & - \\
\hline \multicolumn{6}{|l|}{ Gram-positive bacteria (low GC) } \\
\hline Listeria murrayi & $1.4 \pm 0.5$ & - & - & - & - \\
\hline Planococcus sp. & $17.0 \pm 1.8$ & - & - & - & - \\
\hline \multicolumn{6}{|l|}{ Bacteroides, Flavobacteria } \\
\hline Flavobacterium brevi & $22.8 \pm 1.6$ & $2.4 \pm 0.5$ & $2.4 \pm 0.5$ & - & - \\
\hline
\end{tabular}

No significant cell lysis occurred from 0 to $20 \mathrm{~s}$, but it increased significantly from a mean of $19.0 \pm 2.2 \%$ at $20 \mathrm{~s}$ to a mean of $44.4 \pm 1.8$ and $66.9 \pm 6.3 \%$ when tissue was immersed for 30 and $40 \mathrm{~s}$, respectively (SNK-test, $\alpha=0.05$ ).

\section{Inhibition of bacterial growth by surface extracts of Bonnemaisonia hamifera}

Surface extracts of Bonnemaisonia hamifera clearly inhibited bacterial growth at all test concentrations (Table 4). When tested at the natural concentration, the surface extracts caused wide inhibition zones for Hyphomonas neptunicum and Planococcus sp. The effect on the growth of Vibrio sp. S14 was weaker, but still evident. At the higher test concentrations, 2 and 5 times the natural concentration, the inhibitory effect was generally much larger (Table 4). The control treatments had no effect on bacterial growth (data not shown).

\section{In situ quantification of bacteria on the surface of Bonnemaisonia hamifera}

Individual thalli of Bonnemaisonia hamifera collected from the archipelago west of Tjärnö Marine Biological Laboratory had significantly fewer bacteria on their surfaces compared to the control alga Chondrus crispus (ANOVA, $F_{1,18}=52.88, \mathrm{p}<0.0001$; Fig. 2).

\section{DISCUSSION}

This study was initiated by the screening of the antimicrobial effects of 5 red algal species. The results of the screening assays show that one of the tested species, Bonnemaisonia hamifera, produces metabolites with broad-spectrum effects against bacterial growth. Crude extracts of this alga inhibited growth of 9 of 11 tested bacterial strains. In comparison with the $B$. hamifera extract, the extracts of the other 4 investigated algae produced much less growth-inhibiting effects. All the extracts were tested at concentrations close to the total amount of extractable metabolites obtained from volumes of algal tissue equivalent to the test discs in the agar disc-diffusion assays. Consequently, we concluded that all algal species except $B$. hamifera have no evident potential to produce metabolites with ecologically relevant broad-spectrum effects against bacterial growth. A few earlier studies have also searched for bacterial growth-inhibiting compounds in the same algae as we tested. For example, extracts of Chondrus crispus and Dilsea carnosa produced no growth-inhibiting effects when tested against several marine bacteria (Hellio et al. 2000, 2001), which is in agreement with our results. However, a previous study has also shown that $C$. crispus and D. carnosa may produce metabolites that inhibit the growth of certain bacteria (Hornsey \& Hide 1974). The results from previous studies on bacterial growthinhibiting effects of $B$. hamifera metabolites are more consistent and in agreement with our findings. For 


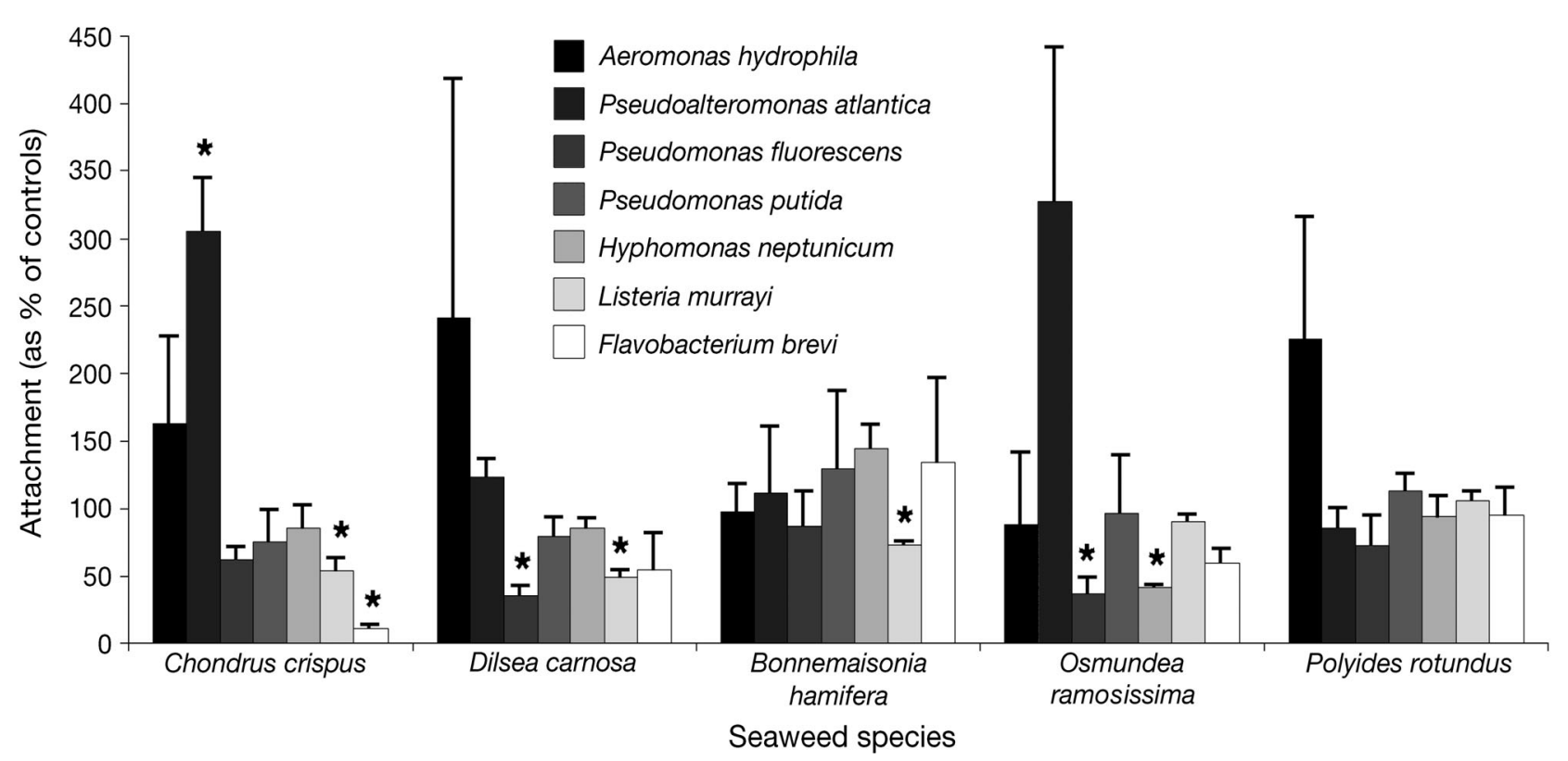

Fig. 1. Effects of crude extracts of Chondrus crispus, Dilsea carnosa, Bonnemaisonia hamifera, Osmundea ramoissima and Polyides rotundes on the attachment (as \% of controls) of the bacteria Aeromonas hydrophila, Alteromonas atlantica, Pseudomonas fluorescens, Pseudomonas putida, Hyphomonas neptunicum, Listeria murrayi and Flavobacterium brevi. Data are means $+\mathrm{SE}, \mathrm{n}=3$. Tested concentrations were $50 \mu \mathrm{g} \mathrm{cm}^{-2}$ for the $B$. hamifera extract and $500 \mu \mathrm{g} \mathrm{cm}{ }^{-2}$ for the rest of the extracts. Significant differences from the controls are indicated by Algal extract * above the bars

Table 4. Growth-inhibiting effects of surface extracts of Bonnemaisonia hamifera tested at 1,2 and 5x the natural concentration against the marine bacteria Hyphomonas neptunicum, Planococcus sp. and Vibrio sp. S14. Data are inhibition zones in $\mathrm{mm} \pm 95 \%$ confidence interval (the diameter of the inhibition zone minus the diametter of the test disc)

\begin{tabular}{|lrrr|}
\hline \multirow{2}{*}{ Test bacteria } & \multicolumn{3}{c|}{ Concentration } \\
\cline { 2 - 4 } & \multicolumn{1}{c|}{$1 \times$} & $2 \times$ & \multicolumn{1}{c|}{$5 \times$} \\
\hline Hyphomonas neptunicum & $12.3 \pm 0.7$ & $22.0 \pm 2.3$ & $45.7 \pm 3.3$ \\
Planococcus sp. & $7.0 \pm 2.0$ & $18.0 \pm 2.0$ & $29.0 \pm 3.0$ \\
Vibrio sp. S14 & $2.2 \pm 0.9$ & $2.3 \pm 0.5$ & $4.0 \pm 0.0$ \\
\hline
\end{tabular}

instance, Hornsey \& Hide (1974) observed strong growth-inhibiting effects of $B$. hamifera thalli introduced into seeded agar, and McConnell \& Fenical (1979) found significant growth-inhibiting activities when testing isolated compounds from $B$. hamifera.

In order for a metabolite to have any ecological antifouling roles against bacteria, it must be presented on the surface of the host, or released into the surrounding water, in sufficient con-

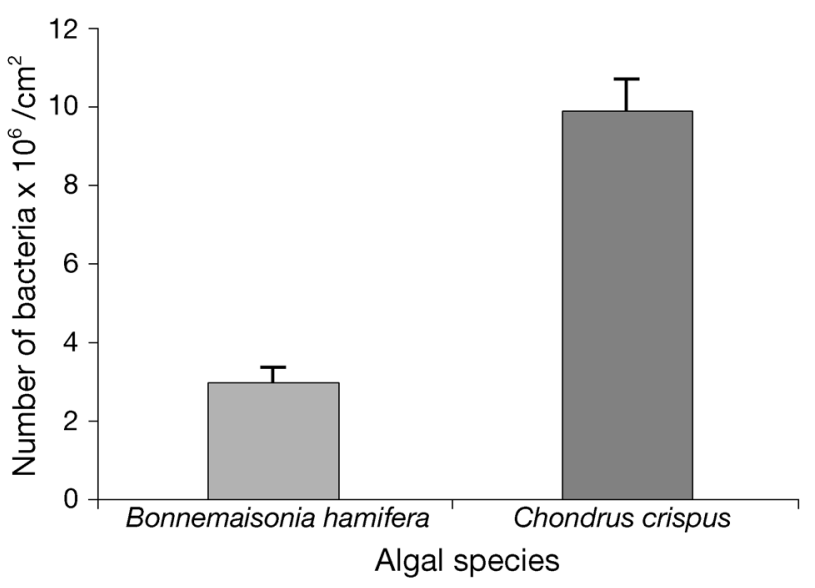

Fig. 2. Bacterial abundances on the surfaces of Bonnemaisonia hamifera and Chondrus crispus collected from the field. Data are means $+\mathrm{SE}, \mathrm{n}=10$ centration to exert an inhibitory effect (Davis et al. 1989, Hay 1996). By extracting surface-associated metabolites and testing them against the growth of 3 marine bacteria, we could show that Bonnemaisonia hamifera has metabolites present on its surface in sufficient amounts to inhibit bacterial growth. Based on this finding, and the results from the bacterial growth tests, which showed that crude extracts of $B$. hamifera contain metabolites with broad-spectrum effects against bacterial growth, we further hypothesized that natural populations of $B$. hamifera would have lower epibacterial abundances compared to co-existing algae that lack such metabolites. The direct counts of bacteria on the surfaces of field-collected B. hamifera and the co-occurring control alga Chondrus crispus, showed that $B$. hamifera had significantly fewer bacteria on its surface compared to C. crispus. In summary, 
our results suggest that $B$. hamifera produces metabolites with broad-spectrum effects against bacterial growth and thereby controls the bacterial abundance on its surface.

As far as we know, only 2 previous studies have demonstrated ecologically relevant effects of algal metabolites on seaweed surface colonization by microorganisms. Kubanek et al. (2003) showed that one isolated compound (lobophorolide) from the brown alga Lobophora variegata inhibited growth of 2 co-occurring fungal species, Dendryphiella salina and Lindra thalassiae, at ecologically relevant concentrations. The other example is the study by Maximilien et al. (1998), where it was shown that naturally occurring surface concentrations of crude extracts and purified compounds, known as halogenated furanones, of the red alga Delisea pulchra inhibited bacterial attachment in the field. Furanones are known to affect quorum sensing in bacteria by inhibiting acetylated homoserine lactone (AHL)-controlled processes (Givskov et al. 1996, Manefield et al. 1999). D. pulchra belongs to the same family as Bonnemaisonia hamifera (Bonnemaisoniacea), but studies on the secondary chemistry of $B$. hamifera have shown that this alga lacks furanones or other structurally similar compounds (McConnell \& Fenical 1979, 1980). Since we only tested crude extracts in our study, we do not know which specific compounds were active against bacterial growth. $B$. hamifera is known to produce polyhalogenated 2-heptanones, and it has previously been shown that the major halogenated compound found in B. hamifera, 1,1,3,3-tetrabromo-2-heptanone, may inhibit bacterial growth (McConnell \& Fenical 1979, 1980). It has been suggested that these halogenated compounds are synthesized in numerous specialized vesicular cells located on the surface of the alga (Wolk 1968, McConnell \& Fenical 1980), from where they can be transported to the surfaces of adjacent cells in order to effectively mediate bacterial colonization. These suggestions are in accordance with our finding that metabolites extracted from the surface of $B$. hamifera inhibit bacterial growth at natural concentrations.

In addition to the bacterial growth experiments, we tested the effects of the algal extracts on bacterial attachment. The results from the attachment tests showed that none of the 5 tested algal extracts had broad-spectrum effects against bacterial attachment at the tested concentrations. However, 4 of 5 algal extracts had some strain-specific effects against bacterial attachment. The extract of Chondrus crispus also significantly stimulated attachment of one bacterial strain, compared to the control. Since the crude extracts tested in this study were complex mixtures of primary and secondary metabolites, some of these metabolites may have been nutrients that potentially could attract motile bacteria to attach (Chet \& Mitchell 1976). All the extracts were tested at concentrations close to the total amount of extractable metabolites yielded from algal tissue with the same surface area as the extracts' residues in the attachment tests (see 'Materials and methods'). Based on the concentrations of extracts, the results from the attachment tests suggest that none of the algal species produce metabolites with broad-spectrum effects against bacterial attachment in order to regulate their epibacterial abundances under natural conditions.

The combined results from the growth and attachment assays with crude algal extracts showed that there was no correlation between the effects on bacterial growth and attachment. This is in accordance with the results from other studies (i.e. Wahl et al. 1994, Slattery et al. 1995, Maximilien et al. 1998, Harder et al. 2003, Kelly et al. 2003), and emphasizes the importance of using several experimental approaches that cover different aspects of the bacterial colonization process (e.g. attachment, growth, swarming), when searching for metabolites that naturally regulate epibacterial abundances on algae or other marine organisms. In contrast to our findings, most of these previous studies (i.e. Wahl et al. 1994, Slattery et al. 1995, Maximilien et al. 1998, Kelly et al. 2003) have detected more activity in the attachment assays compared to the growth assays. Consequently, it has been suggested that behavioral assays, such as attachment tests, are inherently more predictive of ecological functions than assays that simply measure toxicity (i.e. growth inhibition tests) (Engel et al. 2002). We think, however, that it is too early to draw a general conclusion about which type of anti-microbiological mechanism (inhibition of growth, attachment, swarming etc.) prevails in seaweeds or other marine organisms. Firstly, most of the studies using behavioral assays (e.g. attachment tests) have only looked at the effects on a few bacterial strains (i.e. Wahl et al. 1994, Slattery et al. 1995, Kubanek et al. 2002, Harder et al. 2003, Kelly et al. 2003, but see Maximilien et al. 1998), which make generalizations difficult. Secondly, it can be argued that growth-inhibiting mechanisms, just like mechanisms that affect any other stages of the colonization process such as attachment and swarming, have the potential to affect basal characteristics shared by a vast number of bacterial strains, and thereby function as a highly effective defense against a broad spectrum of potential pathogens. This reasoning is supported by the results of this study, which suggests that Bonnemaisonia hamifera produces surface-associated metabolites that naturally inhibit bacterial growth. It is also supported by a recent study, which showed that the epibiotic bacterial community on the soft coral Dendronephthya sp. was distantly related to communi- 
ties on nearby surfaces (Harder et al. 2003). When extracts of the coral were tested for their effects on bacterial growth, it was found that epibiotic bacteria on the coral were much less sensitive to the extracts, compared to nearby benthic bacteria. This indicates that chemical inhibition of bacterial growth was an important factor in explaining the observed difference in the bacterial community profiles on Dendronephthya sp. compared to nearby surfaces.

In conclusion, this study suggests that the red alga Bonnemaisonia hamifera produces surface-associated metabolites that inhibit bacterial growth and thereby control bacterial colonization of its surface. Furthermore, the lack of correlation between the effects on bacterial growth and attachment suggests that multiple tests covering different aspects of the bacterial colonization should be used in combination, when searching for metabolites that naturally regulate epibacterial abundances on algae or other marine organisms.

Acknowledgements. We are grateful to J. Lycken, who helped us with the bacterial growth and attachment tests. The research was supported by the European Union through the European Regional Development Fund (ERDF) Objective 2 West Sweden and by The Swedish Research Council through Contracts 621-2002-289 and 621-2004-2658. The Swedish Research Council for Environmental, Agricultural Sciences and Spatial Planning through Contract 21.0/2003-1119 provided additional support.

\section{LITERATURE CITED}

Aubert M, Aubert J, Gauthier M (1979) Antibiotic substances from marine flora. I. In: Hoppe HA, Levring T, Tanaka Y (eds) Marine algae in pharmaceutical science. Walter de Gruyter, Berlin, p 267-291

Chet I, Mitchell R (1976) Ecological aspects of microbial chemotactic behaviour. Annu Rev Microbiol 30:221-239

Clare AS (1996) Natural product antifoulants: status and potential. Biofouling 9:211-229

Collen J, Delrio MJ, Garciareina G, Pedersen M (1995) Photosynthetic production of hydrogen peroxide by Ulva rigida C. Ag. (Chlorophyta). Planta 196:225-230

Davis A, Targett N, McConnell O, Young C (1989) Epibiosis of marine algae and benthic invertebrates: natural products chemistry and other mechanisms inhibiting settlement and overgrowth. In: Scheuer PJ (ed) Bioorganic marine chemistry, Vol 3. Springer-Verlag, Berlin, p 85-114

de Nys R, Dworjanyn SA, Steinberg PD (1998) A new method for determining surface concentrations of marine natural products on seaweeds. Mar Ecol Prog Ser 162:79-87

Dobretsov SV, Qian PY (2002) Effect of bacteria associated with the green alga Ulva reticulata on marine micro- and macrofouling. Biofouling 18:217-228

Egan S, Thomas T, Holmstrom C, Kjelleberg S (2000) Phylogenetic relationship and antifouling activity of bacterial epiphytes from the marine alga Ulva lactuca. Environ Microbiol 2:343-347

Engel S, Jensen PR, Fenical W (2002) Chemical ecology of marine microbial defense. J Chem Ecol 28:1971-1985
Givskov M, DeNys R, Manefield M, Gram L and 5 others (1996) Eukaryotic interference with homoserine lactonemediated prokaryotic signaling. $\mathrm{J}$ Bacteriol 178: 6618-6622

Harder T, Lau SCK, Dobretsov S, Fang TK, Qian PY (2003) A distinctive epibiotic bacterial community on the soft coral Dendronephthya sp. and antibacterial activity of coral tissue extracts suggest a chemical mechanism against bacterial epibiosis. Fems Microbiol Ecol 43:337-347

Hay ME (1996) Marine chemical ecology: What's known and what's next? J Exp Mar Biol Ecol 200:103-134

Hellio C, Bremer G, Pons AM, Le Gal Y, Bourgougnon N (2000) Inhibition of the development of microorganisms (bacteria and fungi) by extracts of marine algae from Brittany, France. Appl Microbiol Biotechnol 54:543-549

Hellio C, De La Broise D, Dufosse L, Le Gal Y, Bourgougnon N (2001) Inhibition of marine bacteria by extracts of macroalgae: potential use for environmentally friendly antifouling paints. Mar Environ Res 52:231-247

Hornsey B, Hide D (1974) The production of antimicrobial compounds by British marine algae. I. Antibiotic-producing marine algae. Br Phycol J 9:353-361

Johnson CR, Mann KH (1986) The crustose coralline alga, Phymatolithon Foslie, inhibits the overgrowth of seaweeds without relying on herbivores. J Exp Mar Biol Ecol 96: 127-146

Keats DW, Knight MA, Pueschel CM (1997) Antifouling effects of epithallial shedding in three crustose coralline algae (Rhodophyta, Coralinales) on a coral reef. J Exp Mar Biol Ecol 213:281-293

Kelly SR, Jensen PR, Henkel TP, Fenical W, Pawlik JR (2003) Effects of Caribbean sponge extracts on bacterial attachment. Aquat Microb Ecol 31:175-182

Kubanek J, Whalen KE, Engel S, Kelly SR, Henkel TP, Fenical W, Pawlik JR (2002) Multiple defensive roles for triterpene glycosides from two Caribbean sponges. Oecologia 131: $125-136$

Kubanek J, Jensen PR, Keifer PA, Sullards MC, Collins DO, Fenical W (2003) Seaweed resistance to microbial attack: a targeted chemical defense against marine fungi. Proc Natl Acad Sci USA 100:6916-6921

Littler MM, Littler DS (1995) Impact of clod pathogen on pacific coral reefs. Science 267:1356-1360

Manefield M, de Nys R, Kumar N, Read R, Givskov M, Steinberg P, Kjelleberg SA (1999) Evidence that halogenated furanones from Delisea pulchra inhibit acylated homoserine lactone (AHL)-mediated gene expression by displacing the AHL signal from its receptor protein. Microbiol-UK 145:283-291

Maniatis T, Fritsch EF, Sambrook J (1982) Molecular cloning: a laboratory manual. Cold Spring Harbor Laboratory, Cold Spring Harbor, NY

Maximilien R, de Nys R, Holmstrom C, Gram L, Givskov M, Crass K, Kjelleberg S, Steinberg PD (1998) Chemical mediation of bacterial surface colonisation by secondary metabolites from the red alga Delisea pulchra. Aquat Microb Ecol 15:233-246

McConnell OJ, Fenical W (1979) Antimicrobial agents from the marine red algae of the family Bonnemaisoniacea. In: Hoppe HA, Levring T, Tanaka Y (eds) Marine algae in pharmaceutical science. Walter der Gruyter, Berlin, p 479-500

McConnell OJ, Fenical W (1980) Halogen chemistry of the red alga Bonnemaisonia. Phytochemistry 19:233-247

Nylund GM, Pavia H (2005) Chemical versus mechanical inhibition of fouling in the red alga Dilsea carnosa. Mar Ecol Prog Ser 299:111-121 
O'Connor NJ, Richardson DL (1996) Effects of bacterial films on attachment of barnacle (Balanus improvisus Darwin) larvae: laboratory and field studies. J Exp Mar Biol Ecol 206:69-81

Slattery M, McClintock JB, Heine JN (1995) Chemical defenses in Antarctic soft corals: evidence for antifouling compounds. J Exp Mar Biol Ecol 190:61-77

Sridhar KR, Vidyavathi N (1991) Antimicrobial activity of seaweeds. Acta Hydroch Hydrob 19:455-496

Tringali C (1997) Bioactive metabolites from marine algae: recent results. Curr Org Chem 1:375-394

Unabia CRC, Hadfield MG (1999) Role of bacteria in larval settlement and metamorphosis of the polychaete Hydroides elegans. Mar Biol 133:55-64

Underwood AJ (1997) Experiments in ecology: their logical design and interpretation using analysis of variance. Cambridge University Press, Cambridge

Vairappan CS, Suzuki M, Motomura T, Ichimura T (2001)

Editorial responsibility: Howard I. Browman (Associate Editor-in-Chief), Storebø, Norway
Pathogenic bacteria associated with lesions and thallus bleaching symptoms in the Japanese kelp Laminaria religiosa Miyabe (Laminariales, Phaeophyceae). Hydrobiologia 445:183-191

Wahl M (1989) Marine epibiosis I. Fouling and antifouling: some basic aspects. Mar Ecol Prog Ser 58:175-189

Wahl M, Jensen PR, Fenical W (1994) Chemical control of bacterial epibiosis on ascidians. Mar Ecol Prog Ser 110:45-57

Weinberger F, Friedlander M (2000) Response of Gracilaria conferta (Rhodophyta) to oligoagars results in defense against agar-degrading epiphytes. J Phycol 36:1079-1086

Wieczorek SK, Todd CD (1997) Inhibition and facilitation of bryozoan and ascidian settlement by natural multi-species biofilms: effects of film age and the roles of active and passive larval attachment. Mar Biol 128:463-473

Wolk C (1968) Role of bromine in the formation of the refractile inclusions of the vesicle cells of the Bonnemaisoniaceae (Rhodophyta). Planta 78:371-378

Submitted: March 3, 2005; Accepted: May 30, 2005

Proofs received from author(s): October 17, 2005 